\title{
Service Design Guidelines for New Types of Wellness Tourism
}

\author{
Riccardo Bonazzi \\ HES-SO Valais/Wallis, Switzerland \\ Vincent Grèzes \\ HES-SO Valais/Wallis, Switzerland \\ Valérie Barbey \\ HES-SO Valais/Wallis, Switzerland
}

\section{Abstract}

In this article, we describe the preliminary results of an ongoing project aiming at increasing the attractiveness of Alpine destinations in Switzerland, by means of a very widespread hotel. We investigate how to design new services for wellness tourism, which target (a) "young elderly", whose age is comprised between 60 and 75 years, and (b) enterprises interested in meetings, incentives, conferencing and events. The first customer segment is known to be proactive in seeking to improve or maintain health and quality of life, while medical tourists generally travel reactively to receive treatment for a diagnosed disease or condition. The second customer segment mostly seeks for complementary activities to be done after work or as main topic for a seminar. Accordingly, we have conducted interviews with different stakeholders: hotel managers, owners of firms producing natural components for wellbeing and tourist officers. In the end, we highlight a set of relevant findings that should be taken into account when setting up wellness tourism in a dispersed area.

Keywords: wellness tourism, young elderly, destination management JEL classification: M4, Z3

Acknowledgments: The authors would like to thank L. Papadopoulos, A. Pignat and M. Broccard for their relevant contributions to this paper.

\section{Introduction}

Tourism is a fundamental industry in Alpine regions in Europe, even though environmental changes and the entrance of new destinations in Middle East and Asia push most players to reconsider their offering, which are summer activities in the mountain such as hiking and the winter centered on skiing. In the past, alpine destinations have tried to counteract the effect of global warming by increasing their summer activities (Franch, Martini, Buffa, \& Parisi, 2008), but a two-season offering generally suffers from seasonality effect, such as (Lundtorp, 2001): (a) The consequent need to generate a full year's revenue within a short operating season while servicing fixed costs over a twelve month period, (b) Under-utilization of capital assets that are inflexible and, generally, do not have obvious alternative uses and (c) problems of maintaining service and product quality standards in the absence of permanent, long-term employees.

A destination management company (DMC) is in charge of manage the process of definition, promotion and commercialization of the tourism product [originating from within the destination], to generate manageable flows of incoming tourists that 
are balanced, sustainable and sufficient to meet the economic needs of the local actors involved in the destination (Franch and Martini, 2002).

In this article we analyses the expected profitability of a DMC, which is in charge of offering service packages (hotel + wellness activities) in different alpine regions.

The World Health Organisation (WHO) defines wellness as "...the optimal state of health of individuals and groups. There are two focal concerns: the realization of the fullest potential of an individual physically, psychologically, socially, spiritually and economically, and the fulfillment of one's role expectations in the family, community, place of worship and other things." Reasons for the recent development of wellness tourism as a value proposition to tourists are manifold: longer life expectancies, stronger health orientation and the need for self-development in well-developed nations are drivers of health tourism.

Therefore, to counteract the seasonality effect and increase the revenue flows, tourist managers can use the Ansoff matrix to identify different diversification strategies centered on wellness tourism. In this paper we wish to assess two examples of different diversification strategies to increase the overall revenues of hotel managers and of wellness services providers (Ansoff, 1958): (1) A new service for existing customer segments and (B) an existing service for new customer segments.

Once the customer segments, the value propositions and the revenue flows are defined, we intend to use the business model ontology of Osterwalder and Pigneur (2002) to assess under which condition the DMC would be profitable, in terms of components of the cost structure (key activities, key resources and key partners). Therefore, our research question is: how to design the business model of a destination management company for wellness tourism in alpine regions?

In the following section, we review the literature that addresses our research question. The third section illustrates our theoretical model and the fourth section illustrates our preliminary results. The final section discusses limitations of the paper and it suggests future directions of investigation.

\section{Literature review}

The customer segments assessed in this paper comes from the existing literature on wellness tourism, instead the one of health tourism. Indeed, we focus on customers who might wish to do something for their well-being, and we do not treat the case of potential customers, who have to perform certain activities to improve their health.

As suggested by (Franch et al., 2008) new motivations and expectations of tourists in Alpine destinations lead to a set of new offers that combine ecotourism and responsible tourism, and that can be described using four dimensions:

1. Landscape: this dimension appears to be fairly developed in most Alpine destinations, since it has been one of the most relevant dimensions influencing the choice of travelers in the past.

2. Leisure activities: Alpine destinations already offer a set of activities that encompasses skiing, and hiking (for example by special hiking trails and baths). Moreover, recent studies have explored new solutions concerning green mobility to increase the range of activities that a customer can do in a destination.

3. Learning effect: responsible tourism suggests tourists to learn something from the trip itself. Accordingly, wellness tourism in Alpine regions could be an opportunity to learn how to use plants as medications, and to discover scientific studies that support traditional medicine (Hoffmann, FNIMH, \& AHG, 2003). For sake of simplicity, we do not include here professionals in wellness 
services, who seek for training workshops, since the learning effect in this case might be more important than the landscape and the leisure dimensions.

4. Limits: eco-tourists are known to appreciate services that respect the environment and that support the development the society where the hotel is placed. Accordingly, we shall focus on solutions that are green by design.

Regarding the value proposition of a destination management company for wellness tourism, we can identify three main options, which will address the three most profitable customer segments.

The first one concerns customers aged between 30 and 60 years old, with a managerial position in a firm, who have a certain amount of money to spend, a significant amount of stress to deal with during the week and little time available (the weekend). Since this customer segments is already served by hotels in Alpine regions, we shall focus on so-called MICE activities (meetings, incentives, conventions and exhibitions) organized by firms for their managers, which have experienced a $61 \%$ increase since 2011 in Switzerland, especially for what concerns business seminars (MySwitzerland, 2016).

The second one concerns customers, who have more time available to perform wellness tourism. They are aged between 60 and 70 years, and fall into the category of young elderly, with a significant budget available to travel, no significant health issues but awareness that their lifestyle after 75 years old will depend on the care they put on their body.

The third customer segment concerns the service providers for wellness tourism, which are expected to pay a commission fee to support the development and maintenance of the DMC in exchange of a greater amount of customers during the low months with less reservations such as May and November.

In this article, we focus on the most relevant activities of a destination management company, in order to enable wellness tourism in Alpine regions.

For sake of simplicity, we will identify three sets of main processes, described in details by Sainaghi (2006):

- producing and supplying services, which are considered "operative" as they involve the "what to do", which can be referred to as internal activities (Presenza et al., 2005)

- communication, which involves governing a wide array of actions which can attract final clients to the district and publicize the mix of attractions available once they arrive, which can be referred to as external activities (Presenza et al., 2005)

- developing new products which ensure "incremental" or "quantum" growth of district offerings in quantitative and qualitative terms, while recognizing the DMC as a leadership network (Hristov \& Zehrer, 2015).

\section{The proposed business model of the destination management company}

In this section, we briefly illustrate the business model of the DMC and analyze how it relates to existing business models. 
Figure 1

Visualization of the business model of the destination management company

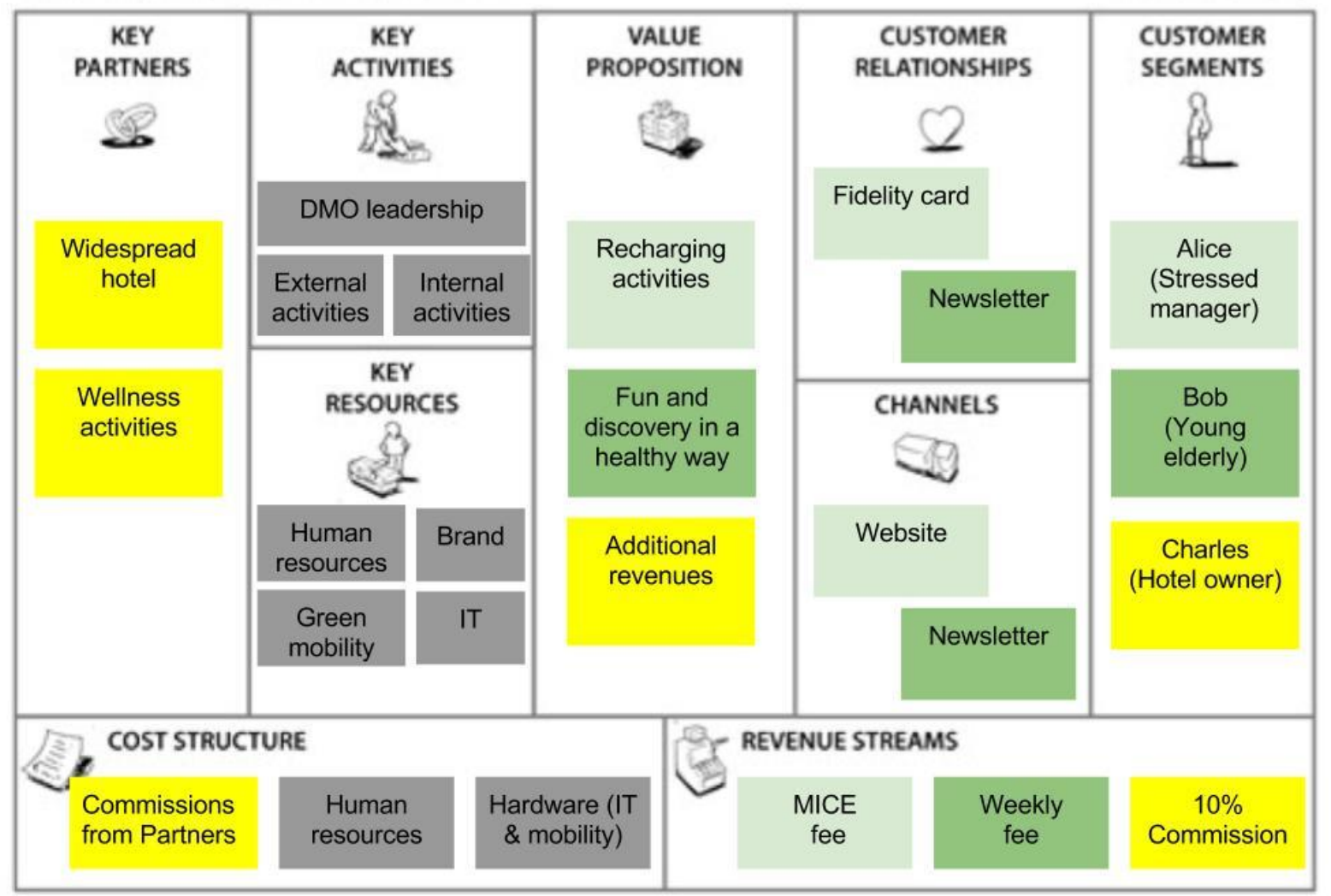

A commission rate in exchange of improved yield management. The young elderlies are offered to do wellness activities during the week, while the MICE segment is offered a space in an authentic landscape and a set of activities focused on wellbeing and stress treatments, as a complement to traditional offers as team-building activities and group hikes. Since these customer segments will reduce the seasonality effect, it should be possible to include a $10 \%$ commission rate to cover the expenses of the DMC. Therefore, our first proposition is:

P1: Hotel owners and activity providers will be willing to pay a commission rate in exchange of out-of-season customers.

Extending the concept of "Albergo diffuso". Presuming inclusion in the network of existing facilities, the infrastructure used by the destination management company to host the customers is a kind of horizontal hotel that is characterised by a whole range of requirements (Dall'Ara, 2010, as translated by (Russo, Lombardi, \& Mangiagli, 2013)), which seems to be well aligned with our business model, with the exception of guideline 8:

1. Management in an entrepreneurial manner: the DMC will be managed by a set of entrepreneurs, in collaboration with public entities as partners.

2. Offer of hospitality and restaurant services: the DMC will take care of external activities (marketing) and internal activities (stakeholders coordination).

3. Living units located in several separate and existing buildings: instead of building large infrastructures, the DMC will connect existing small hotels in a network, to preserve authenticity. 
4. Common services: the presence of premises set out for common areas for guests is necessary (hospitality, bar, restaurants): the DMC will connect the small hotels with premises and infrastructures for MICE activities.

5. The presence of a welcoming community that favours integration in the territory: the MICE will be in charge of external activities.

6. The presence of an authentic environment, easy to associate with the social reality and local culture.

7. The creation of a kind of "symbiotic relationship" among the homes and the areas in question: the DMC will create offers based on authenticity.

8. A distance of no more than 200 or 300 metres between the living units and the structure with the main hospitality services, will be extended by adding a task called mobility management. Indeed, we suggest exploring the possibility to connect different places that can be reached with a 10-minute trip with a set of electric cars offered by the hotels. This sort of very widespread hotel would allow to extend the ranges of activities offered to customers, even though that implies a greater effort in terms of stakeholders alignment, ideally done by the DMC. Accordingly, the new product development can follow the process identified by Droli (2012) for the creation of business opportunities in a widespread hotel.

Therefore, our second proposition is:

P2: If the DMC takes care of mobility management, a segment of customers will be willing to move across a network of activities.

\section{Preliminary assessment of our business model}

In this section, we briefly illustrate our preliminary results obtained by interviewing hotel owners and activity providers in the zone of Val d'Hérens, an alpine valley in the Valais canton of Switzerland.

The results of the occupancy rates of the hotel in the Valais canton can be found on the website www.tourobs.ch. Table 1 illustrates a fictive example of an hotel with 15 rooms. Most hotels appear to have an average occupancy rate of $50 \%$, which can be split into a $80 \%$ occupancy rate during week-ends and a $40 \%$ occupancy rate during the week. In the standard example, we assume that the hotel chooses to set the price at 200 swiss francs per night. Accordingly, the total revenues is CHF $10^{\prime} 800$ and the revenue per available room is CHF $10^{\prime} 800 /(15$ rooms $* 7$ days $)=\mathrm{CHF}$ 103. In the second example, we suppose that the DMC uses the hotel as part of its widespread hotel network. Accordingly, 15 rooms are reserved 3 days per week and - hypothetically- used $50 \%$ of the time over the year, at a lower price to allow bundled offers (hotel + wellness services) at a competitive price. The overall revenue of the second option is CHF 13'800, the occupancy rate goes up to $73 \%$ and the revenue per available room is CHF 131. In this example, the difference between the two options would justify a commission rate for the DMC in commission rate in exchange of additional customers, and our first proposition would be verified. 
Table 1

Comparison of alternatives for a small hotel with 15 rooms

\begin{tabular}{lrr}
\hline & \multicolumn{1}{c}{ Option 1 } & \multicolumn{1}{c}{ Option 2 } \\
\hline Available rooms: segment 1 (week-end) & (2 days) 30 & (2 days) 30 \\
\hline Available rooms: segment 2 (tourists during the week) & (5 days) 75 & (2 days) 30 \\
\hline Available rooms: segment 3 (MICE) & 0 & (3 days) 45 \\
\hline Occupancy rate: segment 1 (week-end) & $80.00 \%$ & $80.00 \%$ \\
\hline Occupancy rate: segment 2 (tourists during the week) & $40.00 \%$ & $90.00 \%$ \\
\hline Occupancy rate: segment 3 (MICE) & $0.00 \%$ & $50.00 \%$ \\
\hline Price: segment 1 (week-end) & CHF200.00 & CHF200.00 \\
\hline Price: segment 2 (tourists during the week) & CHF200.00 & CHF200.00 \\
\hline Price: segment 3 (MICE) & CHF0.00 & CHF160.00 \\
\hline Revenues: segment 1 (week-end) & CHF4,800.00 & CHF4,800.00 \\
\hline Revenues: segment 2 (tourists during the week) & CHF6,000.00 & CHF5,400.00 \\
\hline Revenues: segment 3 (MICE) & CHF0.00 & CHF3,600.00 \\
\hline Total revenues in a week & CHF10,800.00 & CHF13,800.00 \\
\hline Total available rooms used in a week & 54 & 73.5 \\
\hline Occupancy rate & $51.00 \%$ & $70.00 \%$ \\
\hline Revenue per available room & CHF102.86 & CHF131.43 \\
\hline
\end{tabular}

The market demand for wellness services seems to be fairly promising in Switzerland.

Figure 2 shows the amount of searches done on Google for the keywords MICE and ecotourism in the last year. The two trends seems to be somehow correlated, even though the amount of the searches for MICE seems to occur one month sooner sometimes, probably due to the complexity of a large group reservation, while the searches for ecotourism differ in trend during holidays periods (summer and winter). Accordingly, this would confirm our second proposition concerning the potential of the two customer segments, even though the effect of the 10-minute distance on their willingness to pay is still to be verified.

Figure 2

Trends analysis for the keywords MICE and ecotourism between May 2016 and May 2017 (1)

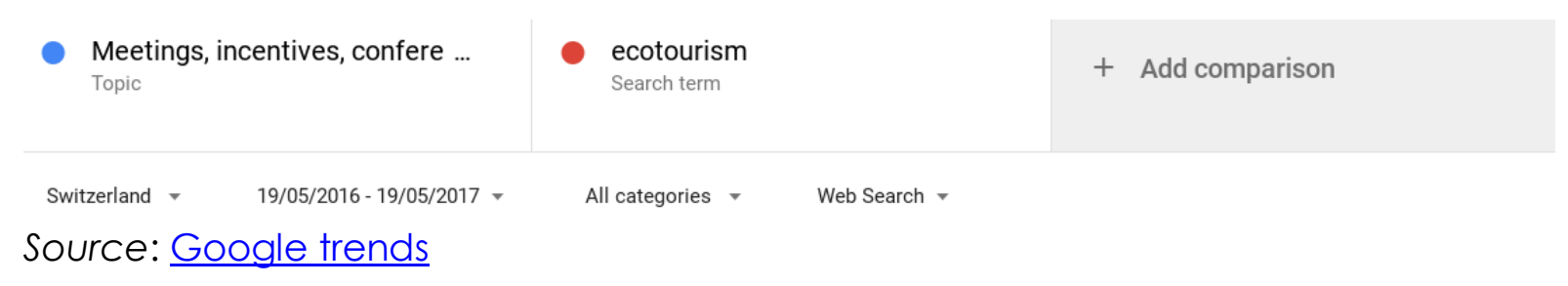


Figure 3

Trends analysis for the keywords MICE and ecotourism between May 2016 and May $2017(2)$

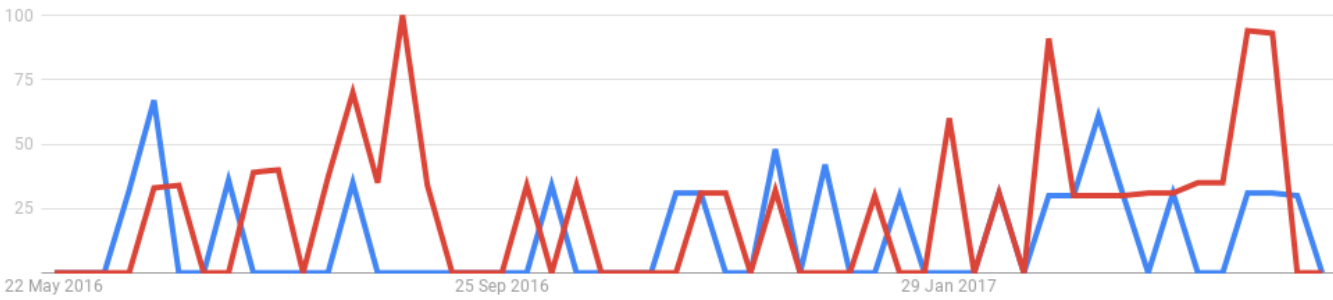

Source: Google trends

\section{Discussions and conclusions}

Our study illustrates a preliminary assessment of the business potential associated with wellness tourism in Alpine regions in Europe. We have identified two customer segments, the young elderly and the MICE which could reduce the seasonality effects and should allow increasing annual profits.

Hence, in order to maintain the authenticity of Alpine regions and to reduce the cost associated with the creation of new infrastructures, we suggest extending the concept of widespread hotel, which states that living units should not be more than 5-10 minutes on foot away from the main hospitality service, towards the concept of very widespread hotel, which states that living units should not be more than 5-10 minutes by car away from the main hospitality service.

Accordingly, we have designed a business model of the destination management company in charge of supervising the creation and maintenance of this service.

In the future, we intend to empirically test our propositions by performing a survey with potential customers and by setting up a prototype in the region of Val d'Herens.

\section{References}

1. Ansoff, H. I. (1958), A Model for Diversification, Management Science, Vol. 4 No.4, pp. 392-414.

2. Droli, M. (2013), II management delle opportunità imprenditoriali 'a chilometro-zero': buone prassi per l'innovazione d'impresa nell'Albergo Diffuso, Atti del XXV Convegno annuale di Sinergie.

3. Franch, M., Martini, U. (2002), Destinations and destination management in the Alps: A proposal for a classification scheme in the light of some ongoing experiences, Paper presented at meeting "Territoires et marchés 2ème colloque de recherche en tourisme de l'Association française des IUP Tourisme, Hôtellerie et Loisirs", Université de Savoie, Site de Chambery.

4. Franch, M., Martini, U., Buffa, F., Parisi, G. (2008), "4L tourism (landscape, leisure, learning and limit): responding to new motivations and expectations of tourists to improve the competitiveness of Alpine destinations in a sustainable way", Tourism Review, Vol. 63 No. 1, pp. 4-14.

5. Hoffmann, D., FNIMH, AHG. (2003), Medical Herbalism: The Science and Practice of Herbal Medicine, Inner Traditions, Bear \& Co.

6. Hristov, D., Zehrer, A. (2015), "The destination paradigm continuum revisited: DMOs serving as leadership networks", Tourism Review, Vol. 70 No. 2, pp. 116-131. 
7. Lundtorp, S. (2001), "Measuring Tourism Seasonality", In Seasonality in Tourism, pp. 2350 .

8. Osterwalder, A., Pigneur, Y. (2002), "An eBusiness model ontology for modeling eBusiness", BLED 2002, Proceedings.

9. MySwitzerland (2016), "Switzerland Meetings Report 2016", available at: http://www.myswitzerland.com/files/?id=74348 (14 March 2017)

10. Presenza, A., Sheehan, L., Ritchie, J. B. (2005), "Towards a model of the roles and activities of destination management organizations", Journal of Hospitality, Tourism and Leisure Science, Vol. 3 No. 1, pp. 1-16.

11. Russo, G., Lombardi, R., Mangiagli, S. (2013), "The Tourist Model in the Collaborative Economy: A Modern Approach", International Journal of Indian Culture and Business Management, Vol. 8 No. 7, available at: https://doi.org/10.5539/ijbm.v8n7pl (11 April 2017)

12. Sainaghi, R. (2006), "From contents to processes: Versus a dynamic destination management model (DDMM)", Tourism Management, Vol. 27 No. 5, pp. 1053-1063.

\section{About the authors}

Riccardo Bonazzi is professor of business model innovation at the University of Applied Science (HES-SO) of Sierre, Switzerland, where he is co-director of the emarketing track. He received his Ph.D. in compliance support systems from the University of Lausanne. His main research interests are IT project management, decision support systems for business model innovation, and information systems for pedagogy. Author can be contacted at riccardo.bonazzi@hevs.ch.

Vincent Grèzes is a professor at HES-SO Valais where he teaches the strategy course. He got his $\mathrm{PhD}$ in market intelligence and strategy and he researches new techniques to combine shared value, crowdsourcing, open innovation and business model design. Author can be contacted at vincent.grezes@hevs.ch.

Valérie Barbey is a professor at HES SO Valais and has worked for more than ten years in R\&D projects in the public sector. She is currently working on new forms of citizen-motivated entrepreneurship, to develop a local economy where communities play an essential role in the development of "dematerialized" and sustainable business models. Author can be contacted at valerie.barbey@hevs.ch. 